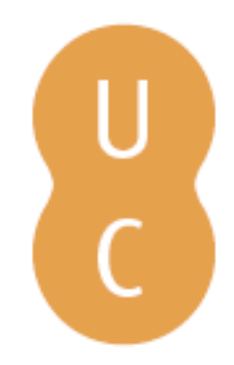

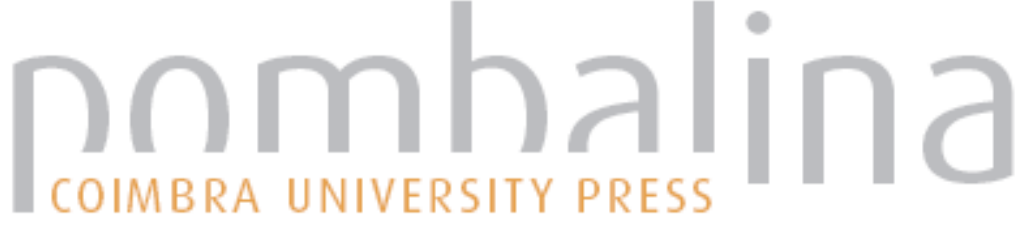

\section{Maturation and strength of adolescent soccer players}
Autor(es):
Fragoso, Isabel; Vieira, Filomena; Castro, Luísa Canto e; Oliveira Junior, Astrogildo

Publicado por: Imprensa da Universidade de Coimbra

URL

persistente:

URI:http://hdl.handle.net/10316.2/38850

DOI:

DOI:http://dx.doi.org/10.14195/978-989-26-1169-3_3

Accessed : $\quad$ 26-Apr-2023 13:51:07

A navegação consulta e descarregamento dos títulos inseridos nas Bibliotecas Digitais UC Digitalis, UC Pombalina e UC Impactum, pressupõem a aceitação plena e sem reservas dos Termos e Condições de Uso destas Bibliotecas Digitais, disponíveis em https://digitalis.uc.pt/pt-pt/termos.

Conforme exposto nos referidos Termos e Condições de Uso, o descarregamento de títulos de acesso restrito requer uma licença válida de autorização devendo o utilizador aceder ao(s) documento(s) a partir de um endereço de IP da instituição detentora da supramencionada licença.

Ao utilizador é apenas permitido o descarregamento para uso pessoal, pelo que o emprego do(s) título(s) descarregado(s) para outro fim, designadamente comercial, carece de autorização do respetivo autor ou editor da obra.

Na medida em que todas as obras da UC Digitalis se encontram protegidas pelo Código do Direito de Autor e Direitos Conexos e demais legislação aplicável, toda a cópia, parcial ou total, deste documento, nos casos em que é legalmente admitida, deverá conter ou fazer-se acompanhar por este aviso.

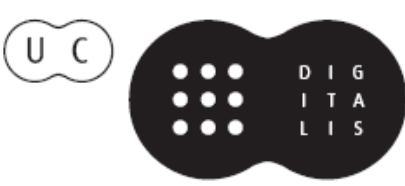




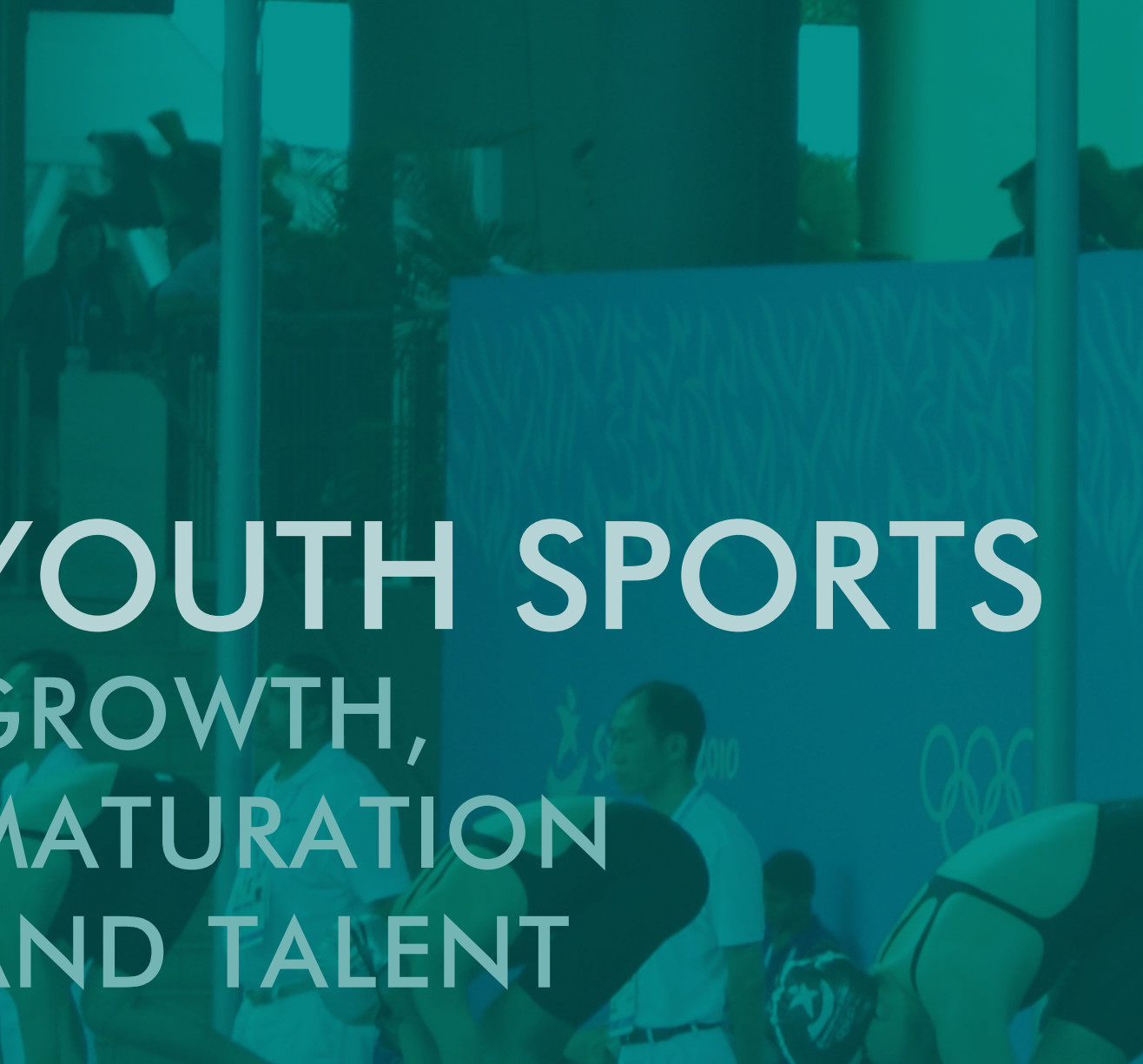

MANUEL J. COELHO E SILVA ANTÓNIO J. FIGUEIREDO MARIJE T. ELFERINK-GEMSER ROBERT M. MALINA

\section{EDITORS}

2. ' EDIÇÃO

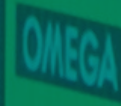

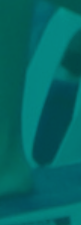




\section{CHAPTER 3: MATURATION AND STRENGTH OF ADOLESCENT SOCCER PLAYERS}

Isabel Fragoso

Filomena Vieira

Luísa Canto e Castro

Astrogildo Oliveira Junior

\section{INTRODUCTION}

Sport training during growth depends on the morphological characteristics and stage of maturation. In boys the association between biological maturation and various anthropometric characteristics is most striking up to about 16 years of age. Motor skill and physical fitness tend to be optimized during adolescence, especially strength and power, which depend in part on fat-free mass (FFM). The onset and termination of adolescence, however, vary considerably among boys, and this may confound the relationship between maturity status and motor performance.

Biologically more mature boys often achieve better performance results and are commonly included among young athletes in baseball, football, soccer, swimming, tennis, and ice hockey (Beunen et al., 1997). However, performance differences among boys of contrasting maturity status within specific age groups are somewhat reduced. This may be related to three factors: the nature of the biological maturation variables and errors of assessment; the specificity of tests used to evaluate motor performance, which may be related to sport modality and may be influenced by training and learning; and the use of mean comparisons which limits appreciation of variability among individuals.

This study evaluates different methods of maturity assessment in young soccer players in an attempt to identify the best combination of indicators that can differentiate among individuals of contrasting maturity status during adolescence. It also considers the association between morphological and maturational characteristics, and muscular strength to estimate variation associated with maturity status. 


\section{METHODS}

The sample included 71 boys, 13 to 16 years of age, who attended one of Portuguese top soccer clubs located in the Lisbon metropolitan area. Time spent in sport-specific training was, on average, 8 hours/week, which is less than one-half of the amount of time spent on training in elite sport schools in other countries, about 18-30h/week plus a specific number of days at sport camps (Malina et al., 1997).

Anthropometric dimensions were obtained following the protocol in Fragoso and Vieira (2000). The dimensions included measures of overall body size (weight and height, the body mass index [BMI] was calculated), segment lengths (sitting height, arm length, leg length), skeletal breadths (biacromial, biiliocristal, biepicondylar humerus and femur, stylion ulna), skinfolds (biceps, triceps, subscapular, iliac crest, abdominal, thoracic, axillary, thigh, medial calf), and girths (relaxed and tensed [flexed] arm, forearm, thigh, calf). Strength was measured with three tests, the contra movement jump, maximal leg strength and handgrip strength. Handgrip strength was used as the primary strength variable for detailed analysis.

Measures of maturity status included skeletal age and stages of sexual development. Skeletal age of left hand and wrist was assessed by an experienced rater blinded to the chronological age (CA) of the subjects. Thirteen bones were rated with the Tanner-Whitehouse III Method (TW3). The TW is the method of choice in most growth studies (Gilli, 1996). Sexual maturity status was self-evaluated on the basis of five stages of pubic hair [PIP5] and genital [GI-G5] development) using the criteria of Tanner (1962). Age of voice was obtained prospectively according to the proposed criteria of Cameron (personal communication). Permission from parents and from the boys (self assent) were obtained before data collection.

Descriptive statistics were calculated for the total sample and single year age groups. The data was examined for collinearity and nonparametric correlations between indicators of maturity were done. Principal component analysis of the three indicators of sexual maturity was used to derive a maturation index based on the factor score. The subjects were then divided into three sexual maturity categories (SMC): initial stages (IS), median stages (MS), and last stages (LS) of sexual maturation. IS and LS had factor scores that were, respectively, less or more than 0.5 standard deviations from the mean.

A multiple nonparametric comparison test (Kruskal-Wallis) involving rank orders and an ANOVA and SCHEFFE techniques were used to test differences in handgrip strength among the three maturity groups. A linear 
model was developed for handgrip strength and maturity category to examine the influence of morphological and maturity variables on strength. The probabilities of $\mathrm{F}$ for entrance and removal of the variables were of 0.05 and 0.10 for all variables. The analyses were carried out with SPSS II.5 software for Windows.

\section{RESULTS}

Table I. Means and standard deviations handgrip strength, chronological age and skeletal age.

\begin{tabular}{lcccc}
\hline & Mean & SD & Max & Min \\
\hline Handgrip (kg) & 43.3 & 10.5 & 66.0 & 24.0 \\
Bone age (yrs) & 14.9 & 1.80 & 16.5 & 10.0 \\
Chronological age (yrs) & 14.7 & 1.10 & 16.9 & 13.1 \\
Bone age-Chronological age (years) & 0.12 & 1.28 & 2.87 & -3.40 \\
\hline
\end{tabular}

Descriptive statistics for handgrip strength, chronological age (CA) and skeletal age (SA) are summarized in Table I. Corresponding statistics for CA, SA, strength and anthropometric variables are summarized by single year age categories from 13 to 16 in Table 2. Most of the subjects studied presented a slightly advanced biological age (SA) compared to CA.

The variables presented in Table 2 were used in the regression and were selected after the intercorrelations and dimensionality of anthropometric, SA and sexual maturity were analysed. Mean SA is very similar to CA in 13 and 14 year old boys, and then is in advance of CA among 15 year old boys until 15 years. Among 16 year old boys, SA and CA are about equal as boys approached skeletal maturity or were already skeletally mature. As expected, height increases between age groups from 13 to 15 years, and then is about identical in 15 and 16 year old boys. Upper leg length and stylion-ulnar, biepicondylar femur and maleolar breadths do not differ significantly between 13 and 16 years. The same is true for the thigh, calf and axillary skinfold thicknesses. In general, trunk breadths, especially biacromial breadth, and arm and thigh girth increase with age.

Table 3 summarizes the distribution of stages of sexual maturity in the total sample of boys. There is variation among maturity indicators, but the majority of boys are in stages comprised between 3 and 5. Box plots (Figure I) show the relationship between bone age and the three indicators of sexual maturity. Almost the entire sample has subjects within level four and five for pubic hair, in level three for voice stage, which means that these subjects have voice alterations for less than two years, and is between level three and four of genital development. At level three of voice and genital stage bone age vary 
between 10 to 16 years although quite symmetrically on both directions of the mean when speaking about voice stage. The variability of bone age considering the different stages of development of pubic hair is smaller than the one observed for the previous described sexual characteristics.

Table 2. Means and standard deviations of all variables by single year age groups.

\begin{tabular}{|c|c|c|c|c|c|c|c|c|}
\hline & \multicolumn{2}{|c|}{$\begin{array}{c}13 \text { yrs } \\
(n=27)\end{array}$} & \multicolumn{2}{|c|}{$\begin{array}{c}14 \mathrm{yrs} \\
(\mathrm{n}=17)\end{array}$} & \multicolumn{2}{|c|}{$\begin{array}{l}15 \mathrm{yrs} \\
(\mathrm{n}=13)\end{array}$} & \multicolumn{2}{|c|}{$\begin{array}{c}16 \mathrm{yrs} \\
(\mathrm{n}=14)\end{array}$} \\
\hline Chronological Age & 13.6 & 0.2 & 14.6 & 0.2 & 15.5 & 0.3 & 16.5 & 0.3 \\
\hline Bone Age (years) & 13.4 & 1.5 & 14.9 & 1.5 & 16.2 & 0.7 & 16.5 & 0.0 \\
\hline BA-CA & -0.23 & 1.54 & 0.34 & 1.47 & 0.74 & 0.89 & 0.01 & 0.29 \\
\hline Stature $(\mathrm{cm})$ & 162.2 & 8.5 & 168.6 & 10.7 & 175.2 & 6.1 & 174.7 & 5.4 \\
\hline Weight (kg) & 53.4 & 9.7 & 59.1 & 10.7 & 67.3 & 4.7 & 72.1 & 6.0 \\
\hline Sitting height (cm) & 84.2 & 4.7 & 88.0 & 6.0 & 91.3 & 2.8 & 92.2 & 3.1 \\
\hline Body Mass Index $\left(\mathrm{kg} / \mathrm{m}^{2}\right)$ & 20.1 & 1.9 & 20.6 & 1.6 & 21.9 & 1.0 & 23.6 & 1.7 \\
\hline Upper Arm Length $(\mathrm{cm})$ & 33.5 & 1.9 & 34.0 & 2.6 & 35.7 & 2.0 & 39.1 & 11.4 \\
\hline Upper Leg Length (cm) & 41.6 & 2.3 & 45.2 & 12.8 & 44.3 & 2.8 & 44.3 & 2.6 \\
\hline Thoracic Length (cm) & 17.1 & 1.6 & 19.2 & 1.8 & 20.4 & 1.6 & 19.1 & 1.9 \\
\hline Biepic. Humer. Breadth $(\mathrm{cm})$ & 6.4 & 0.5 & 6.5 & 0.5 & 6.9 & 0.4 & 6.9 & 0.5 \\
\hline Stylion-ulnar Breadth (cm) & 5.3 & 0.6 & 5.4 & 0.6 & 5.5 & 0.4 & 5.6 & 0.2 \\
\hline Biepic. Femur Breadth $(\mathrm{cm})$ & 9.3 & 0.9 & 9.0 & 0.5 & 9.6 & 0.6 & 9.3 & 0.4 \\
\hline Malleolar Breadth (cm) & 10.0 & 14.4 & 7.4 & 0.4 & 8.3 & 2.7 & 7.7 & 0.4 \\
\hline Biacromial Breadth $(\mathrm{cm})$ & 34.9 & 2.5 & 36.0 & 2.6 & 37.8 & 1.6 & 39.0 & 1.6 \\
\hline Torax Transv. Breadth (cm) & 24.8 & 1.9 & 25.3 & 1.8 & 26.1 & 1.3 & 28.5 & 2.2 \\
\hline Torax Sagital Breadth $(\mathrm{cm})$ & 16.6 & 1.7 & 15.7 & 2.0 & 16.7 & 1.0 & 19.2 & 1.6 \\
\hline Biiliocristal Breadth (cm) & 23.8 & 1.8 & 24.7 & 2.4 & 25.4 & 2.3 & 26.9 & 1.6 \\
\hline Tensed Arm Girth $(\mathrm{cm})$ & 25.4 & 2.4 & 27.2 & 2.3 & 29.7 & 1.7 & 31.1 & 1.6 \\
\hline Thigh Girth $(\mathrm{cm})$ & 46.5 & 3.5 & 47.4 & 4.0 & 50.8 & 2.4 & 54.4 & 2.1 \\
\hline Calf Girth (cm) & 33.7 & 3.0 & 35.8 & 2.4 & 37.1 & 1.3 & 37.9 & I.1 \\
\hline Thoracic Girth (cm) & 74.3 & 5.7 & 78.3 & 5.2 & 82.3 & 1.4 & 86.3 & 3.9 \\
\hline Abdominal Girth (cm) & 70.7 & 4.8 & 74.5 & 5.4 & 78.5 & 3.0 & 79.7 & 5.0 \\
\hline Biceps Skinfold (mm) & 4.1 & 0.9 & 4.4 & 1.3 & 4.5 & 1.5 & 5.3 & 1.2 \\
\hline Triceps Skinfold (mm) & 8.1 & 2.4 & 8.9 & 3.3 & 8.7 & 2.0 & 11.0 & 3.7 \\
\hline Thigh Skinfold (mm) & 11.5 & 3.3 & 11.8 & 4.0 & 10.8 & 3.0 & 12.4 & 2.3 \\
\hline Calf Skinfold (mm) & 8.0 & 2.3 & 8.8 & 3.1 & 7.7 & 2.5 & 9.1 & 3.5 \\
\hline Subscapular Skinfold (mm) & 6.5 & 1.3 & 7.3 & 2.0 & 8.0 & 1.1 & 9.6 & 2.4 \\
\hline Axilar Skinfold (mm) & 5.4 & 1.2 & 5.3 & 1.1 & 5.5 & 1.0 & 6.3 & 2.5 \\
\hline Abdominal Skinfold (mm) & 8.4 & 2.6 & 9.0 & 4.1 & 10.5 & 3.2 & 13.0 & 5.4 \\
\hline Handgrip (kg) & 33.9 & 6.4 & 45.3 & 9.1 & 50.5 & 5.0 & 52.6 & 7.3 \\
\hline
\end{tabular}


Table 3. Total number of boys in each level of genitalia, pubic hair and voice development.

\begin{tabular}{llcccc}
\hline & & & Stage & & \\
\hline Indicator & 1 & 2 & 3 & 4 & 5 \\
Pubic hair & 1 & 1 & 5 & 36 & 28 \\
Genital & 0 & 20 & 33 & 13 & 5 \\
Voice & 0 & 3 & 30 & 16 & 22 \\
\hline
\end{tabular}

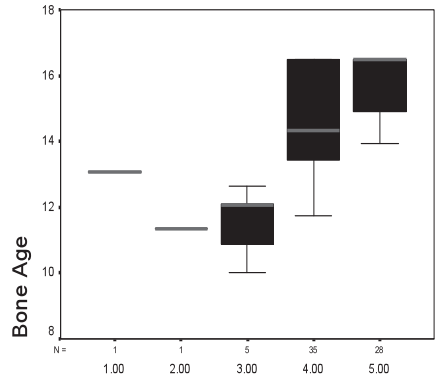

Pubic Hair

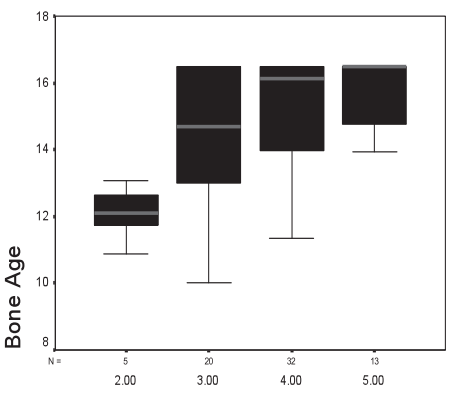

Genital Stage

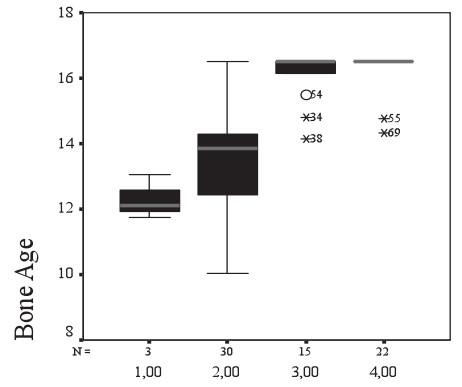

Voice Stage

Figure I. Box-Plots for bone age by stage of by sexual maturity

Stages of sexual maturity are associated with considerable variation in skeletal maturity. This suggests that skeletal and sexual maturation are not necessarily synchronous, although SA and stage of sexual maturity are scored on mathematically different scales and the number of pre- and early-pubertal boys in the sample is quite small. Nonparametric correlations between SA and stage of sexual maturity are significant: voice, $r=0.82$; pubic hair, $r=0.50$; and genitalia, $r=0.31$.

The principal components analysis of the three indicators of sexual maturity yielded one component with an eigen value >1.0. It accounted for 
$67 \%$ of the variance (Table 4). Although results were very similar for the three indicators, pubic hair was most highly related with the first principal component (Table 5). The unstandardized 'sexual maturity index' (SMI) for this sample of $13-16$ year old boys was: $\mathrm{SMI}=0.405 \times \mathrm{VS}+0.561 \times \mathrm{PH}+$ $0.480 \times$ GSA.

Table 4. Initial eigenvalues and total variance explained by sexual maturational variables (pubic hair, genitalia development and voice alteration).

\begin{tabular}{cccc}
\hline Component & Eigen Value & \% of Variance & Cumulative \% \\
\hline 1 & 2.00 & 66.9 & 66.9 \\
2 & 0.59 & 19.6 & 86.5 \\
3 & 0.40 & 13.5 & 100 \\
\hline
\end{tabular}

Table 5. Correlations with the first component.

\begin{tabular}{l|c}
\hline & Component I \\
\hline Voice Stage (VS) & 0.785 \\
Pubic Hair (PH) & 0.863 \\
Genital Stage (GS) & 0.803 \\
\hline
\end{tabular}

Table 6 shows the correlations between handgrip strength, bone age, each indicator of sexual maturity and the sexual maturity index (SMI). Handgrip strength is related with bone age, voice stage and SMI. As expected, the three indicators of sexual maturity and the SMI are highly intercorrelated

Table 6. Matrix of correlations of different sexual maturation variables.

\begin{tabular}{lcccccc}
\hline & $H G$ & BA & VS & PH & GS & SMI \\
\hline Handgrip & - & 0.75 & 0.73 & 0.38 & 0.24 & 0.53 \\
Bone Age & & - & 0.83 & 0.50 & 0.31 & 0.66 \\
Voice Stage & & - & 0.46 & 0.35 & 0.73 \\
Pubic Hair & & & - & 0.55 & 0.84 \\
Genital Stage & & & & - & 0.79 \\
SMl & & & & & & - \\
\hline All coefficients are significant, $\mathrm{P} \leq 0.05$. & & & & &
\end{tabular}

To study the association of handgrip and maturity, the sample was divided into three maturity categories as described in the methods (Table 7). More mature subjects are significantly stronger than less mature boys between $13-16$ years. Post hoc multiple comparisons indicate that there are significant differences between the IS and LS, and between IS and MS, but no difference between MS and LS (Table 8). 
To further evaluate the association of handgrip strength and maturity, several highly correlated variables were considered in an attempt to reduce the dimensionality. The correlation matrix and the corresponding proximity tree showed that bone age in boys is strongly correlated with limb girths. Linear dimensions also had high intercorrelations, so one or two variables were chosen as representative. According to the correlation matrix and dendrogram, almost all girth variables were not included in the statistical treatment. The stepwise method was used to adjust the linear regression model for handgrip strength. The variables chosen for each maturity group were obtained assuming that all the covariates could enter in the full model.

Table 7. Kruskal Wallis test for differences in handgrip strength among sexual maturity groups

\begin{tabular}{cccc}
\hline HG & Stage & $\mathrm{N}$ & Mean Rank \\
\hline Initial & 15 & $14.3 \mathrm{~kg}$ \\
& Median & 29 & $38.0 \mathrm{~kg}$ \\
& Last & 27 & $45.9 \mathrm{~kg}$ \\
\hline$H G$ & Chi-Square & Df & P value \\
& 23,087 & 2 & 0.000 \\
\hline
\end{tabular}

Table 8. Multiple comparison of handgrip strength among the three sexual maturity groups (nonparametric tests).

\begin{tabular}{|c|c|c|c|c|}
\hline \multicolumn{2}{|c|}{ Group } & Mean Difference & Standard Error & Significance \\
\hline Initial & $\begin{array}{l}\text { Last } \\
\text { Median }\end{array}$ & $\begin{array}{l}-31.57 \mathrm{~kg}^{*} \\
-23.73 \mathrm{~kg} *\end{array}$ & $\begin{array}{l}5.51 \\
5.44\end{array}$ & $\begin{array}{l}.00 \\
.00\end{array}$ \\
\hline Last & Median & $7.83 \mathrm{~kg}$ & 4.57 & .24 \\
\hline
\end{tabular}

* $p<0.05$ level.

Results of the regressions are summarized in Table 9. Bone age appears in the regression only for the total sample. This suggests a role fo variation in biological maturity in handgrip strength across the age range 13-16 years. Within the specific maturity categories, CA appears a predictor in the MS and LS groups, but not in the IS. This may reflect the limited age range of the sample of boys in the early stage of sexual maturation. It is of interest that skeletal dimensions appear among the significant predictors of strength in the least mature group (IS). Finally the robustness of arm bones also influences the handgrip result. 
Table 9. Four adjusted linear regression models for "handgrip strength" for the all sample and for each maturational group level.

\begin{tabular}{lcccc}
\hline & $\begin{array}{c}\text { Total } \\
\text { Sample }\end{array}$ & IS & MS & LS \\
\hline Boys & Coef. & Coef. & Coef. & Coef. \\
\hline (Constant) & -67.159 & -27.040 & -50.722 & -27.358 \\
Bone Age & 2.064 & & & \\
Chronological Age & 4.025 & & 6.370 & 4.355 \\
Upper Leg Length & & -1.405 & & \\
Biacromial Breadth & & 1.042 & & \\
Stylion-ulnar Breadth & 3.765 & & & \\
Malleolar Breadth & & 11.382 & & 1.306 \\
\hline R Square & 0.66 & 0.85 & 0.44 & 0.57 \\
Adjusted R Square & 0.64 & 0.81 & 0.41 & 0.53 \\
Standard error & 6.31 & 2.18 & 8.42 & 5.01 \\
\hline
\end{tabular}

\section{DISCUSSION}

This group of soccer players at 13 years is composed of boys who are only slightly later maturing; their bone ages are slightly lesser than their chronological ages $(-0.23)$. The 15 year old players, on the other hand, are significantly advanced in skeletal maturity; bone age is advanced over CA by along one year (Table 2). These trends suggest that late maturing boys may give-up soccer or may be systematically removed from training programs. On the other hand, the sport of soccer may systematically select for boys advanced in maturity as adolescence progresses. The small difference between 15 and 16 year old boys probably reflects reduced variation as the end of adolescence is approaching.

Biological maturity can be assessed in several ways, and the two more commonly used methods are based on secondary sex characteristics and skeletal age. This study attempted to combine these methods with moderate success. The majority of this sample of soccer players were in stages four and five for pubic hair, which is consistent with observations that boys practicing sport enter each stage of genital and pubic hair development earlier than nonathletes (Malina et al., 1997).

Indicators of sexual maturity vary somewhat with overall bone age variability, so that skeletal and sexual maturation do not necessarily proceed synchronously. The nonparametric correlations between stage of each indicator of sexual secondary and bone age were 0.83, 0.50 and 0.31 , respectively, for stage of voice, pubic hair and genitalia. The variable results 
may reflect error associated self-evaluation and bone age assessment, and also the different scales used for sexual maturity (5 stages) and bone age (continuous). There is also the possibility of population variation in indicators of biological maturation (Kemper et al., 1997).

Bone age and chronological age were major predictors of handgrip strength in the total sample (Table 9). This may suggest that in similar circumstances of biologic age, chronological age becomes an important factor in variability. This in turn may reflect the advanced experience and longer training history of the older soccer players compared to the younger players. The robustness of wrist bones also appeared as a predictor of handgrip strength in this sample of boys.

Within the three maturity categories, bone age did not appear as a predictor of strength; rather, in the MS and LS categories, chronological age was the major predictor. In contrast, in IS, skeletal breadths were the major predictors of handgrip strength. Once again, the role of chronological age may be reflected in experience and longer training history.

\section{CONCLUSIONS}

- $\quad$ High commonality of indicators of sexual maturity suggests that it may be desirable to work with only one indicator. A weighted vector like SMI based on voice, pubic hair and genital development is a potential method including all three criteria.

- Bone age is an most important explanatory variable of handgrip strength.

- The use of a regression model to predict handgrip strength may be especially useful during the initial stages of pubertal maturation.

- It is important that the findings of the present study be replicated in other and larger samples of soccer players and participants in other sports.

\section{REFERENCES}

Baxter-Jones AD (1995). Growth and development of young athletes. Should competition levels be age related? Sports Med, 20 (2), 59-64.

Beunen G. (1993). Biological maturation and physical performance. In W Duquet, JAP

Day (Eds). Kinanthropometry IV. London; New York: E \& F Spon. 
Beunen GP, Malina RM, Lefevre J, Claessens AL, Renson R, and Simons J (1997). Prediction of adult stature and noninvasive assessment of biological maturation. Med Sci Sports Exerc, 29 (2), 225-230.

Bielicki T, Koniarek J, Malina RM (1984). Interrelationships among certain measures of growth and maturation rate in boys during adolescence. Ann Hum Biol, I I (3), $201-210$.

Carter JEL. (1988). Somatotypes of Children in Sports. In RM Malina (Ed.), Young Athletes. Biological, Physiological and Educational Perspectives (pp. 153-165). Champaign, IL: Human Kinetics.

Fragoso I, Vieira F (2000). Morfologia e crescimento. Curso prático. Cruz Quebrada, Portugal: Faculdade de Motricidade Humana.

Gilli G (1996). The assessment of skeletal maturation. Horm Res, 45 Suppl 2, 49-52.

Kemper HC, Post GB, Twisk JW (1997). Rate of maturation during the teenage years: nutrient intake and physical activity between ages 12 and 22. Int J Sport Nutr, 7 (3), 229-240.

Malina RM (1989). Growth and Maturation: Normal Variation and Effect Training. In CV Gisolfi, DR Lamb (Eds.), Perspectives in Exercise Science and Sports Medicine. Vol. 2, pp. 223-265.. Indianapolis, Indiana: Benchmark Press.

Malina RM, Woynarowska, B, Bielicki T, Beunen G, Eweld D, Geithner CA (1997). Prospective and retrospective longitudinal studies of the growth, maturation, and fitness of Polish youth active in sport. Int I Sports Med, I 8 Suppl 3, SI 79- 185.

Malina RM, Bouchard C (199I). Growth maturation and physical activity. Campaign, IL: Human Kinetics.

Mueller WH, Cho SD, Meininger JC, Liehr P, Chan W (200I). Strategies for combining and scaling sexual maturity indicators: the Heartfelt Study. Ann Hum Biol, 28(4), 422-430.

Tanner JM (1962). Growth at Adolescence, second edition. Oxford: Blackwell Scientific Publications.

Vieira F, Fragoso I, Silva L, Canto e Castro L (2002). Morphology and sports performance in children aged 10-13 years: Identification of different levels of motor skills. In T Reilley, M Marfell-Jones (Eds), Kinanthropometry VIII. London: Taylor and Francis.

Ackowledgement: The authors thank Professor Barry Bogin and Dr. Teresa Vargas for their kind help in the revision of this article. 